\title{
ジャイロ型発電機の受動制御
}

高 橋 智 幸* 岩 崎淳* 保 坂寛*

\section{Passive Control of Gyroscopic Power Generator}

\author{
Tomoyuki Takahashi*, Jun Iwasaki* and Hiroshi Hosaka*
}

\begin{abstract}
The gyroscopic power generator produces a high-speed rotation of magnets from low-frequency vibrations and supplies electric power to information and communication devices that use human vibrations in daily life. In this paper, in order to increase the stability and the output power of the generator, a simple equation that indicates the steady state approximate solution of phase difference is derived. From the derived solution, the phase difference of the precession angle is used as a margin factor of the stability. The control methods for the steady state and the transient state are then verified by the simulations. In an experiment to determine precession angle, a measurement method is developed in which the sensing coil is attached perpendicular to the generation coil and precession angle is obtained from the envelope of the coil voltage. In order to maintain the stability and high power generation for variable input vibrations, the impedance control method using the phase difference is developed and verified experimentally.
\end{abstract}

Key Words: Gyroscope, Power Generator, Vibration, Passive Control, Impedance Control

\section{1.は じめに}

情報通信デバイスの小型化により，人間抢よびあらゆる人工 物，自然物にセンサを装着し，インターネット上で情報交換を 行うユビキタス情報システムが実現しつつある。 その課題の一 つに, 電源の確保がある. ユビキタスシステムでは多数のセン サや情報機器を用いるため, 二次電池では充電の手間が膨大と なり，一次電池では交換の手間と使用ずみ電池による環境問題 が生じる.この解決策として, 機器に発電機を内蔵し, 携帯時や 使用時に発電・充電を行う環境発電の研究が活発化している $[1]$. 環境発電として有望なものは, 振動, 光, 熱であり, これらは いずれも腕時計用に実用化されている [2]. このうち，振動によ る発電は, 強制的な振動により大出力の緊急充電が可能, 発電 機を装着者の行動センサとして利用可能, かばんやポケットの 中など使用場所の自由度が高いなどの利点がある. 腕時計用の 振動発電機では, 手首の姿勢変化により偏心錘を回転させ, 電 磁誘導により数 $\mu \mathrm{W}$ の発電を行い, 時計の消費電力 $1[\mu \mathrm{W}]$ を 賄っている $[3] \sim[7]$. その他, 共振を用いて運動エネルギーを取 り込み, 静電誘導, 圧電などにより電気エネルギーに変換する 多数の振動発電機が試作されているが, 携帯サイズの場合, 出 力はたかだか $1[\mathrm{~mW}]$ である。一方，一般の情報機器，例えば 微弱無線では $10[\mathrm{~mW}]$, 携帯電話では $1[\mathrm{~W}]$ 程度の電力が必要

原稿受付 2010 年 12 月 20 日

*東京大学

*The University of Tokyo

ロ 本論文は学術性で評価されました。
であり，発電機の大幅な高出力化が必要となっている。

この解決のため, 筆者らは, ジャイロ効果を用いて発電量を大 幅に増大する発電機を開発している。回転体の自転と歳差運動 を組み合わせ，入力振動の数十倍の自転運動を発生する機構が Archie L. Mishler により考案されている [8]. 本機構は Dynabee という運動遊具に利用されてきたが, これに電磁誘導機構 を組み込み, 発電機として利用するものである. 従来の発電機 はいずれも内部のおもりの単振動を用いている。この場合，お もりから得られる仕事率は, 質量 $\times$ 質点加速度 $\times$ 加振速度で あり, 人の振動では加速度, 速度ともに小さいため発電量が小 さい，一方ジャイロ型発電機では，自転するおもりの傾き振動 を用いており，仕事率は，慣性能率 $\times$ 自転角速度 $\times$ 加振角速 度の 2 乗で与えられる。自転が高速であれば, 振動が微小でも 仕事率は大きくなり, 加振源からは, あたかもおもりの質量が 増大したように感じる。

本機構については, Gulick らによる傾頭回転運動に対する定 常運動解析 [9], 筆者らによる振動発電機の試作と過渡応答解析 の研究 $[10] \sim[12]$ が行われている. その結果, ジャイロ型発電 機は $1[\mathrm{~W}]$ 程度と高出力が得られるが, 安定性が低いことが明 らかとなった。この解決策として, 筆者らは発電機のコイルに 外部から電流を流し，一時的に発電機をモータとして作用させ る自己起動法を考案した [12]. しかしこの方法ではエネルギー を消費するため，発電機としての平均出力が低下する。そこで 本研究では, 受動素子のパラメータ制御のみで, エネルギーを 消費することなく安定性を向上させる方法を提案する．以下で はまず，振動入力に対するロータの運動解析を行い，定常状態 
高橋智幸岩 崎

の安定性指標として位相差を導出する. 次に, 位相差を用いて 受動的に電磁誘導回路のインピーダンスを制御し, 回転を安定 化する方法を提案し, シミュレーションにより有効性を確認す る. 最後に実験により, 本手法により発電量を 6 倍に増大した 例を示す.

\section{2. ロータ運動の解析}

\section{1 ジャイロ型発電機の構造と運動方程式}

ジャイロ型発電機の構造を Fig. 1 に示す. $y$ 軸回りに自転す るロータがあり，その軸は上下二つのトラックにより支えられ ている。トラックの間隔はロー夕軸の直径よりわずかに大きく 隙間があり，ロータ軸は片方のトラック面とだけ接触する。ロー 夕が自転しているときにトラックに $x$ 軸回りの振動を加えると, 角運動量の法則によりロータに $z$ 軸回りのトルクが発生し, 歳 差運動を始める。 また，ロータ軸は上下別々のトラックと接し, 摩擦力は自転速度を増加させる方向に働く、ロータに磁石を取 り付け, トラックの周りに発電コイルを巻き, 電磁誘導により 発電する.

振動入力に対するロータの運動方程式と定常状態の近似解は 文献 [11] で導かれている。本節でその概要を説明する。Fig. 1 で空間に固定された直角座標系を $E$ 座標系とし, トラックは初 期状態で $E_{1}, E_{2}$ 面内にあり， $E_{2}$ 軸回りに $\theta=\theta_{0} \sin \left(\omega_{0} t\right)$ で 摇動回転するものとする. $\theta_{0}$ は入力振幅, $\omega_{0}$ は角周波数であ る. トラックに固定した座標系を $e_{t}$ 座標系, ロータの歳差運動 とともに回転する座標系を $e$ 座標系とし, 歳差回転角 $\left(e_{t 1}\right.$ 軸 と $e_{1}$ 軸のなす角) を $\alpha$, 自転角 ( $e_{1}$ 軸回りのロータの回転角) を $\gamma$ とする. $E$ 座標系から見たロータの角速度ベクトル $\vec{\omega}_{r}$ は, $E$ 座標系から見たトラックの角速度 $\dot{\theta} \vec{E}_{2}, e_{t}$ 座標系から見た ロータの歳差角速度 $\dot{\alpha} \vec{e}_{t 3}, e$ 座標系から見たロータの自転角速 度 $\dot{\gamma} \vec{e}_{1}$ の和であり, $\vec{E}_{2}$ および $\vec{e}_{t 3}$ を $e$ 座標系で表すことによ $\eta$, 次式を得る。

$$
\begin{aligned}
\vec{\omega}_{r} & =\dot{\theta} \vec{E}_{2}+\dot{\alpha} \vec{e}_{t 3}+\dot{\gamma} \vec{e}_{1} \\
& =(\dot{\gamma}+\dot{\theta} \sin \alpha) \vec{e}_{1}+(\dot{\theta} \cos \alpha) \vec{e}_{2}+\dot{\alpha} \vec{e}_{3}
\end{aligned}
$$

トラックとロータ軸の半径比を $\xi$ と, トラックとロータ軸の 間にすべりがなければ, 次式が成り立つ。

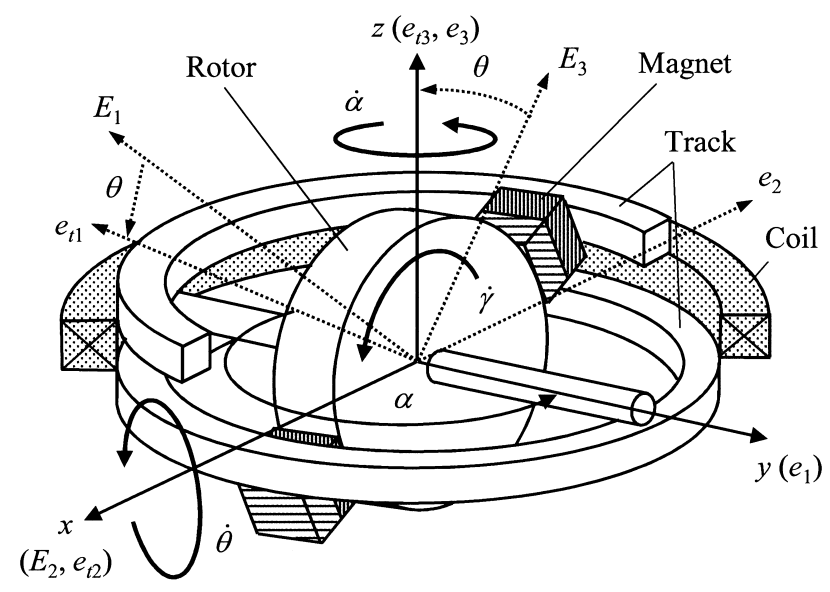

Fig. 1 Structure of the gyroscopic power generator
淳保坂宽

$$
\dot{\gamma}=\xi \dot{\alpha}
$$

式（2）を式（1）に代入して， $\omega_{r}$ を $\alpha$ のみで表し，またロー 夕には自転速度に比例する粘性トルク $\sigma \dot{\gamma} \vec{e}_{1}$ が働くものとして, $e$ 座標系において角運動量とトルクの関係式（オイラー方程式） を立てると，次式を得る。

$$
\begin{aligned}
& \ddot{\alpha}\left(\xi^{2} I_{1}+I_{2}\right)+\xi I_{1} \ddot{\theta} \sin \alpha+\left(I_{2}-I_{1}\right) \dot{\theta}^{2} \sin \alpha \cos \alpha \\
& \quad+\xi^{2} \sigma \dot{\alpha}=0
\end{aligned}
$$

ここで, $I_{1}$ はロータの軸周りの慣性能率, $I_{2}$ は半径回りの慣性 能率, $\sigma$ は減衰係数である.

式 (3) がロー夕の運動方程式であるが, 非線形なため解析解 は導出できない. そこで, 定常状態ではロータの歳差運動と卜 ラックの振動が同期し, またロータの自転速度 $\dot{\gamma} は 一$ 定と仮定 して, 定常状態における近似解を導出する. まず $\alpha$ と入力位相 $\omega_{0} t$ の位相差 $\varphi$ を次式で定義する.

$$
\alpha=\varphi+\omega_{0} t
$$

式（4）を式（3）に代入し, 入力振動の一周期 $\left(2 \pi / \omega_{0}\right)$ で積 分平均し, さらに $\xi \gg 1$ を用いると, 定常状態における $\varphi$ の 近似解 $\varphi_{0}$ が, 次式のように求まる.

$$
\cos \varphi_{0}=\frac{2 \xi \sigma}{I_{1} \omega_{0} \theta_{0}}
$$

\section{2 定常状態の安定性}

式（5）は定常状態を示すが, 安定性まで保証するものではな い. そこで本研究ではまず安定性を判定する。近似解 $\varphi_{0}$ の近 傍の微小振動 $\varepsilon$ を考える.

$$
\alpha=\omega_{0} t+\varphi_{0}+\varepsilon
$$

式（6）を式（3）に代入し，\&について線形化すると次式を得る.

$$
\begin{aligned}
& \ddot{\varepsilon}\left(\xi^{2} I_{1}+I_{2}\right)+\dot{\varepsilon} \xi^{2} \sigma \\
& \quad+\varepsilon\left[\begin{array}{l}
\xi I_{1} \ddot{\theta} \cos \left(\omega_{0} t+\varphi_{0}\right) \\
+\left(I_{2}-I_{1}\right) \dot{\theta}^{2}\left\{\cos ^{2}\left(\omega_{0} t+\varphi_{0}\right)-\sin ^{2}\left(\omega_{0} t+\varphi_{0}\right)\right\}
\end{array}\right] \\
& \quad+\xi I_{1} \ddot{\theta} \sin \left(\omega_{0} t+\varphi_{0}\right)+\xi^{2} \sigma \omega_{0} \\
& \quad+\left(I_{2}-I_{1}\right) \dot{\theta}^{2} \sin \left(\omega_{0} t+\varphi_{0}\right) \cos \left(\omega_{0} t+\varphi_{0}\right)=0
\end{aligned}
$$

ロータ回転は, 定常回転, 低周波で大振幅の過渡振動, 高周 波で微小振幅の定常振動から構成されることが先行研究ならび に次章で示されている，そこで過渡振動のみが安定性に寄与す ると仮定し, またその周期は入力振動周期より十分長いことに 着目して, 式 $(7)$ を入力振動の一周期 $\left(2 \pi / \omega_{0}\right)$ について積分 平均し, $\varepsilon, \dot{\varepsilon}, \ddot{\varepsilon}$ はその間一定とみなす。すると次式を得る.

$$
\begin{aligned}
& \ddot{\varepsilon}\left(\xi^{2} I_{1}+I_{2}\right)+\dot{\varepsilon} \xi^{2} \sigma \\
& +\varepsilon\left[\begin{array}{l}
\frac{1}{2} \xi I_{1} \theta_{0} \omega_{0}{ }^{2} \sin \varphi_{0} \\
+\frac{1}{4}\left(I_{2}-I_{1}\right) \theta_{0}{ }^{2} \omega_{0}{ }^{2} \cos 2 \varphi_{0}
\end{array}\right]=0
\end{aligned}
$$

第 1 項, 第 2 項の係数は常に正である. もし第 3 項の係数が正 であれば, 系は安定な減衰振動系となる。第 3 項の係数を $k$ と 置き, 変形すると次式を得る。 


$$
\begin{aligned}
k= & \frac{1}{2}\left(I_{1}-I_{2}\right) \theta_{0}{ }^{2} \omega_{0}{ }^{2} \sin ^{2} \varphi_{0}+\frac{1}{2} \xi I_{1} \theta_{0} \omega_{0}{ }^{2} \sin \varphi_{0} \\
& -\frac{1}{4}\left(I_{1}-I_{2}\right) \theta_{0}{ }^{2} \omega_{0}{ }^{2}
\end{aligned}
$$

これが正であるための条件は以下である.

$$
\sin \varphi_{0}>\frac{1}{2}\left\{\begin{array}{l}
-\frac{I_{1}}{I_{1}-I_{2}} \cdot \frac{\xi}{\theta_{0}} \\
+\sqrt{\left(-\frac{I_{1}}{I_{1}-I_{2}} \cdot \frac{\xi}{\theta_{0}}\right)^{2}+2}
\end{array}\right\}
$$

式（5）（10）が同時に成り立つことが, 安定な定常状態が存 在する条件である. 実際の発電機のパラメータを用いて, 入力 振幅の大きさを $0[\mathrm{rad}]$ から $0.524[\mathrm{rad}]$ の間で変化させると, 式 (10）の $\varphi_{0}$ の下限は $5.24 \times 10^{-5}[\mathrm{rad}]$ から $1.90 \times 10^{-3}[\mathrm{rad}]$ の間となり，ほほ $0[\mathrm{rad}]$ とみなる。 また式（5）の右辺はす べて正であるから， $\varphi_{0}<\pi / 2$ が必要である. したがって安定 な定常状態の範囲は, 次式のように求まる。

$$
0<\varphi_{0}<\pi / 2
$$

次に, 安定性と発電量を最適化する条件を考える. 発電量 $P$ は, 粘性減衰力がすべて電力になるとすれば次式で与えられる。

$$
P=\sigma \dot{\gamma}^{2}=\sigma \xi^{2} \omega_{0}^{2}
$$

したがって発電量は $\sigma$ が大きいほど大きくなる。 しかし $\sigma$ が 大きすぎると式（5）の右辺が 1 より大きくなり, 式（5）を満 たす $\varphi_{0}$ が存在しなくなる。したがって, 発電量が大きくかつ 安定な系とするには, 式 (5) の右辺が 1 , すなわち $\varphi_{0}$ が 0 と なればよい. 式 (5) に含まれるパラメータのうち $\xi, I_{1}, I_{2}$ は 機構によって決定し， $\theta_{0}, \omega_{0}$ は入力振動によって決定するため, 動作中に変化させることができない. 一方 $\sigma$ はコイル巻数や負 荷インピーダンスなど受動素子のインピーダンスにより変化さ せることができる、したがって, 動作中の $\varphi_{0}$ を測定し, $\varphi_{0}$ が なるべく小さくなるように $\sigma$ を動的に変化させればよい. この 方法によれば，エネルギー消費がないことに加え， $\varphi_{0}$ のみ測 定すれば制御が行える， $I_{1}, \theta_{0}, \sigma$ などの機構および入力パラ メータが不要なため, 正確な制御が容易である. $\varphi_{0}$ の測定方法 は 3 章で述べる。

\section{3 定常状態の制御可能性}

式（3）を数值的に解き, $\sigma$ と $\theta_{0}$ がゆっくり変化した場合 のロータの運動特性を求めた. 機構および振動条件は 3 章の実 験装置の值 $I_{1}=4.6 \times 10^{-5}\left[\mathrm{kgm}^{2}\right], \quad I_{2}=3.5 \times 10^{-5}\left[\mathrm{kgm}^{2}\right]$, $\xi=32.9, \quad \omega_{0}=4 \pi[\mathrm{rad} / \mathrm{s}]$ とした.

Fig. 2 に, 入力振幅 $\theta_{0}$ をゆっくり増減させた場合の $\varphi$ の 変化を示す. $\sigma$ を一定 $\left(\sigma=2.5 \times 10^{-6}\left[\mathrm{kgm}^{2} / \mathrm{s}\right]\right)$ として, $\theta_{0}$ を点線のように変化させたところ， $\varphi$ は実線のように変化した。 $\theta_{0}$ の増減に対応して $\varphi$ が滑らかに変化し, $\theta_{0}$ と $\varphi$ が一対一の 関係にあることが分かる. また $\theta_{0}$ が小さく $\varphi<0$ となると, $\varphi$ は急激に減少している。これは, 安定回転が得られず, 失速 したことを示す。なおここで与えた $\sigma$ は, 実験装置における減 衰と同程度の值である. Fig. 3 に, $\sigma$ をゆっくり増減させた場 合の $\varphi$ の変化を示す. $\theta_{0}$ を一定 $\left(\theta_{0}=\pi / 9[\mathrm{rad}]\right)$ として, $\sigma$

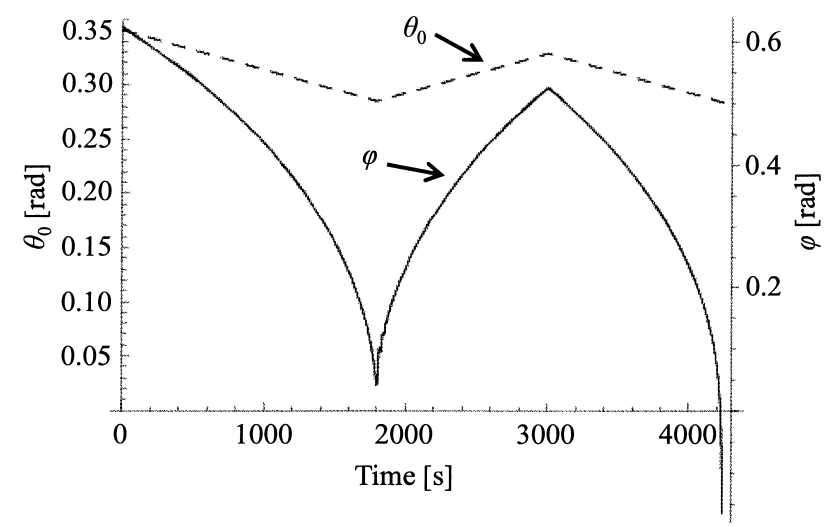

Fig. 2 Change in $\varphi$ when $\sigma$ is constant and $\theta_{0}$ changes slowly

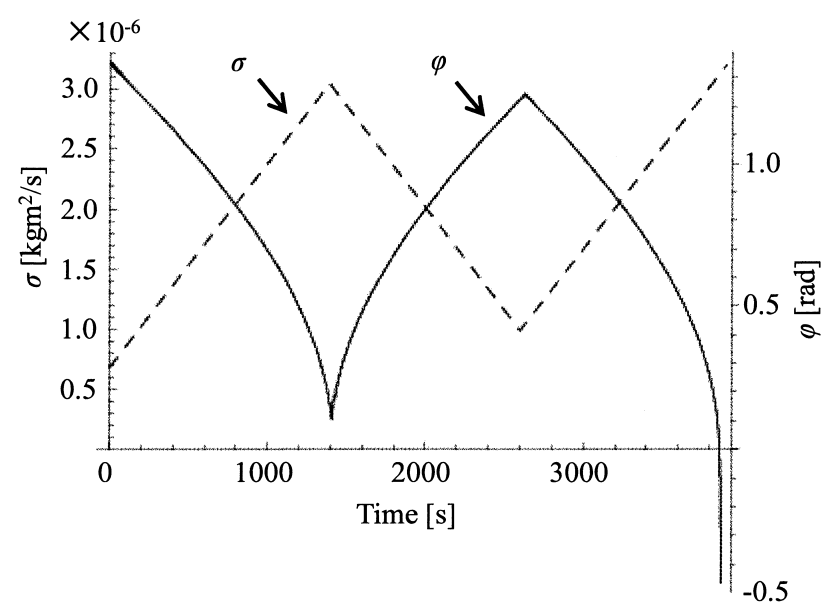

Fig. 3 Change in $\varphi$ when $\theta_{0}$ is constant and $\sigma$ changes slowly

を点線のように変化させたところ $\varphi$ は実線のように変化した Fig. 2 と同様に, $\sigma$ と $\varphi$ は一対一の関係にあり, $\varphi<0$ では $\varphi$ が急激に減少し失速している.

以上により, $\varphi>0$ の範囲で $\sigma$ と $\theta_{0}$ がゆっくり変化する場 合には， $\sigma$ の変化により $\varphi$ を任意の值に設定できること，およ び， $\varphi=0$ が安定限界であることを確認できた. すなわち，入 力振動が変化しても， $\varphi=0$ となるように $\sigma$ を変化させれば, 系を安定かつ発電量最大に保つことができる。

\section{4 過渡状態の制御可能性}

入力振動が急変する場合には, 定常状態が安定であってもそ こに至る過渡状態で不安定になる場合がある. 式 (3) を数值的 に解き, 安定な場合と不安定な場合が存在することを確認した.

まず， $\varphi, \dot{\varphi}$ の初期值が定常解に近い場合，つまり定常状態 にある発電機への入力振動をわずかに変え, 別の定常状態に 移行する場合の過渡特性を計算した。 $\theta_{0}=0.44[\mathrm{rad}]$ の定常 状態 $\varphi=0.75[\mathrm{rad}], \dot{\varphi}=0[\mathrm{rad} / \mathrm{s}]$ を初期值とし, $\theta_{0}=$ $\pi / 9[\mathrm{rad}]$ に入力振幅を階段状に変化させた場合の $\varphi$ の時間 変化を Fig. 4 に, 位相平面上での $\varphi, \dot{\varphi}$ の関係を Fig. 5 に示 す. $\sigma=2.8 \times 10^{-6}\left[\mathrm{kgm}^{2} / \mathrm{s}\right]$ である.このときは $\varphi, \dot{\varphi}$ ともに 一定值に収束し, 新たな定常回転に落ち着くことが分かる. 式 （5）による $\varphi_{0}$ の近似解は $0.42[\mathrm{rad}]$ であり, Fig. 4, Fig. 5 の 収束值はこれと一致している。なお，位相平面における細かい 波は, 振動に同期した微小振動成分である. 


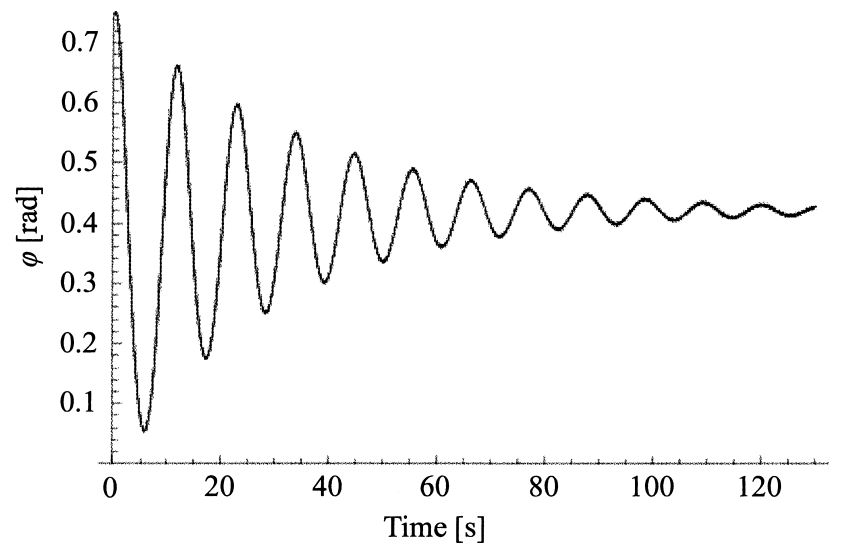

Fig. 4 Change in $\varphi$ when the rotor is stable

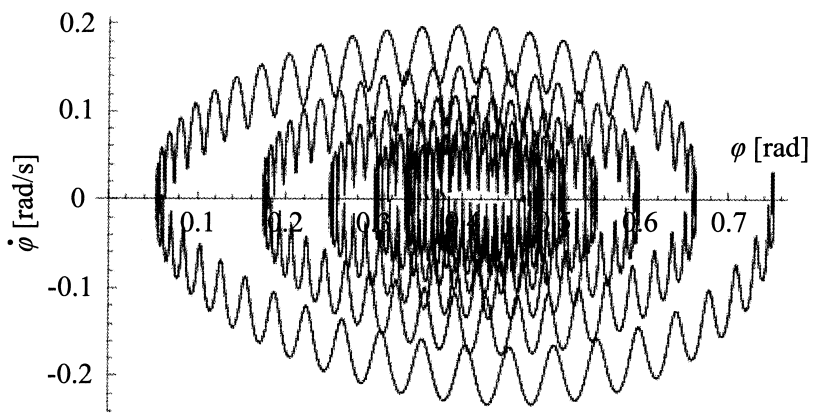

Fig. 5 Phase plane of $\varphi$ when the rotor is stable

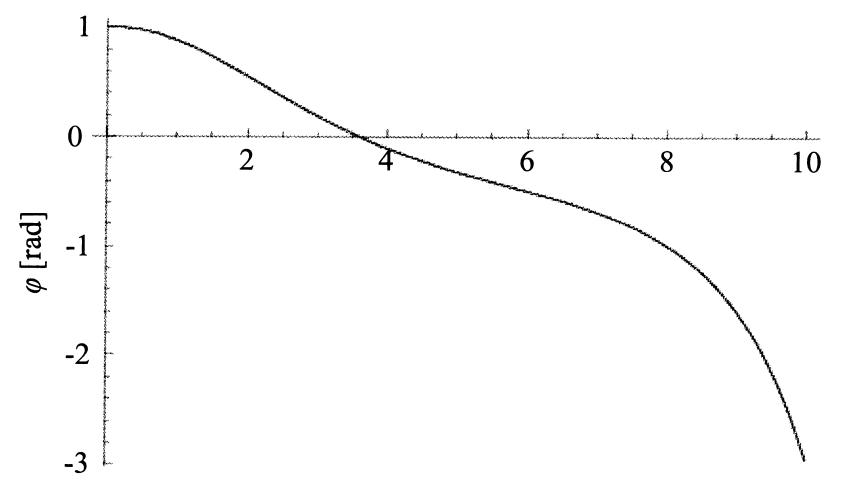

Time $[\mathrm{s}]$

Fig. 6 Change in $\varphi$ when the rotor is transiently unstable

次に $\varphi, \dot{\varphi}$ の初期值が定常解から大きくずれる場合, つまり入 力振幅が大きく変化する場合の定常状態から別の定常状態への 移行を計算した. $\theta_{0}=0.59[\mathrm{rad}]$ から $\theta_{0}=\pi / 9[\mathrm{rad}]$ に変化さ せる場合を想定し, 初期值 $\varphi(0)=1.0[\mathrm{rad}], \dot{\varphi}(0)=0[\mathrm{rad} / \mathrm{s}]$ として, Fig. 4, Fig. 5 と同様の計算を行った. Fig. 6 は $\varphi$ の 時間変化であり, 振動せず単調に減少している. Fig. 7 は位相 平面図であり, $\varphi, \dot{\varphi}$ は渦巻きを描くことなく, 第 3 象限で無限 遠に延びている。これらは $\dot{\alpha}=0$ すなわちロータが失速したこ とを示す。以上により, 入力振動が急変する場合には, 定常状 態が安定であっても過渡的に不安定となり得ることが分かった。

次に，過渡的な不安定を回避する方法を提案する。式 (3) か ら過渡状態の安定条件を見出すことは難しいため, 定常状態の

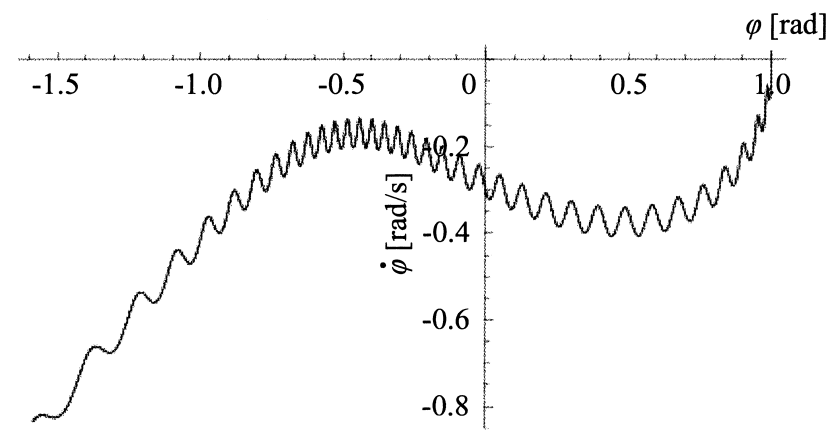

Fig. 7 Phase plane of $\varphi$ when the rotor is transiently unstable

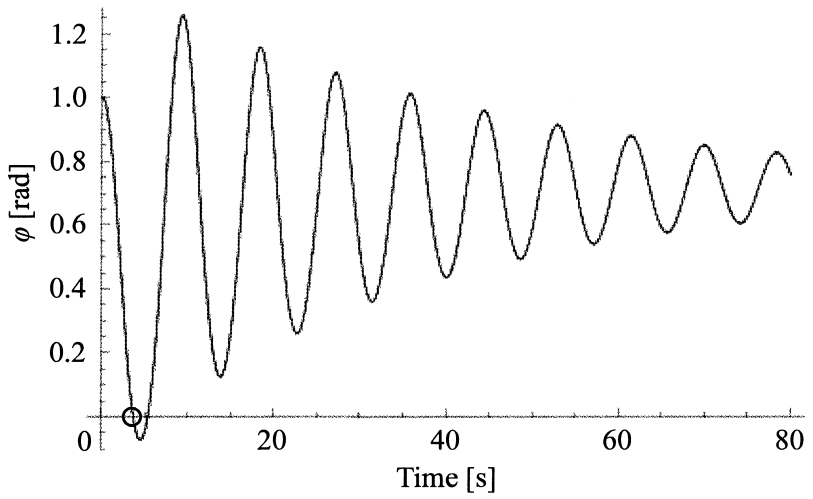

Fig. 8 Change in $\varphi$ when $\sigma$ decreases at the point denoted by the circle

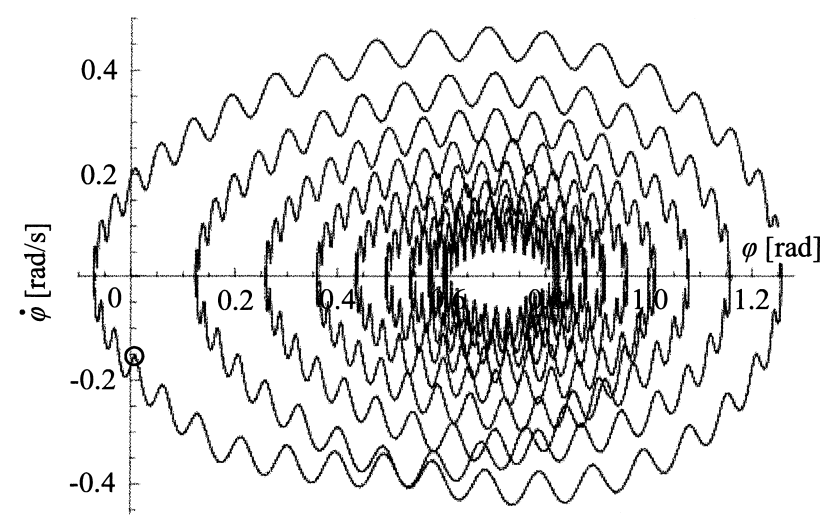

Fig. 9 Phase plane of $\varphi$ when $\sigma$ decreases at the point denoted by the circle

安定化法を流用する，定常状態では， $\varphi=0$ が安定限界であり， また， $\sigma$ が小さいほど安定性が向上する。そこで，過渡状態に おいても， $\varphi$ が 0 に近づいたところで $\sigma=0$ とする安定化制 御を試みる。

初期条件として, 過渡的に不安定となる条件 $\varphi(0)=1.0[\mathrm{rad}]$, $\dot{\varphi}(0)=0[\mathrm{rad} / \mathrm{s}]$ を与え, $\varphi=0$ となったときに $\sigma$ を $2.8 \times 10^{-6}\left[\mathrm{kgm}^{2} / \mathrm{s}\right]$ から $2.3 \times 10^{-6}\left[\mathrm{kgm}^{2} / \mathrm{s}\right]$ に減少させた 他のパラメータは Fig. 6, Fig. 7 と同じである. Fig. 8 にの 時間変化を, Fig. 9 に $\varphi$ と $\dot{\varphi}$ の位相平面図を示す.丸で示 した位置で $\sigma$ を減少させることで，安定を回復できた。たた し， $\varphi=0$ で $\sigma$ を減少させれば必ず安定となる訳ではない. 例えば，定常状態からさらに大きくずれた初期条件 $\varphi(0)=0$, 
$\dot{\varphi}(0)<-1.3[\mathrm{rad} / \mathrm{s}]$ では, $\sigma=0$ としても安定化しないこと がシミュレーションで確認された，この場合には，外部からエ ネルギーを与えて $\sigma$ を負とする自己起動 $[13]$ が必要となる.

\section{3. 検 証 実 験}

計算結果の妥当性を検証するため, インピーダンス制御の実 験を行った. Fig. 10 に実験装置の概念図, Fig. 11 に発電機の 外観を示す。回転機構には Dynabee を用い, ロータにネオジ ウム磁石を内蔵し, 外殼に発電コイルを巻いている. 発電機を サーボモータとモータコントローラにより正弦波状に摇動加振 する. 加振方向は Fig. 10 の Input の向きである. そして, 発 電コイルから外部抵抗に加わる電圧をオシロスコープで測定し, 発電量 $P$ を抵抗值と電圧值から計算する. 発生電圧が交流であ り, 時間変化するため, オフラインで電圧值を積分して平均電 力を求めた. サーボモータからは, 加振角度 $\theta$ が 0 (水平) の 瞬間にパルスが出され，これにより発電機が水平となる時間を 検出する。実用化時には, 発電機に加速度計を取り付け, 入力 振動を測定することを想定している。ロータの位相差 $\varphi$ を測 定するため, 発電コイルに対して垂直にセンシングコイルを巻 いている. センシングコイルは, ロータの歳差角 $\alpha$ により誘導 電圧が変化する.二つのコイルの波形の実測值を Fig. 12 に示 す. 自転速度が一定の場合, 発電コイルの電圧は一定であるが,

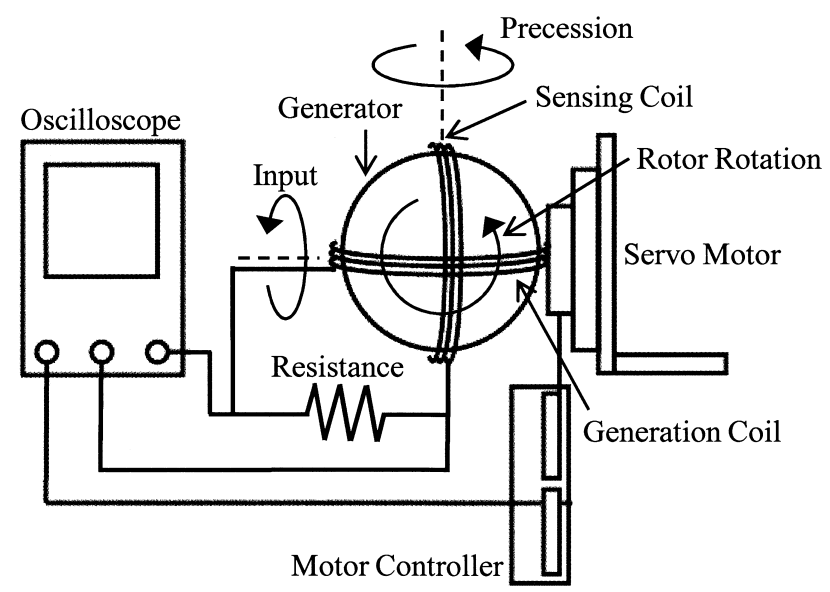

Fig. 10 Schematic diagram of the measurement system

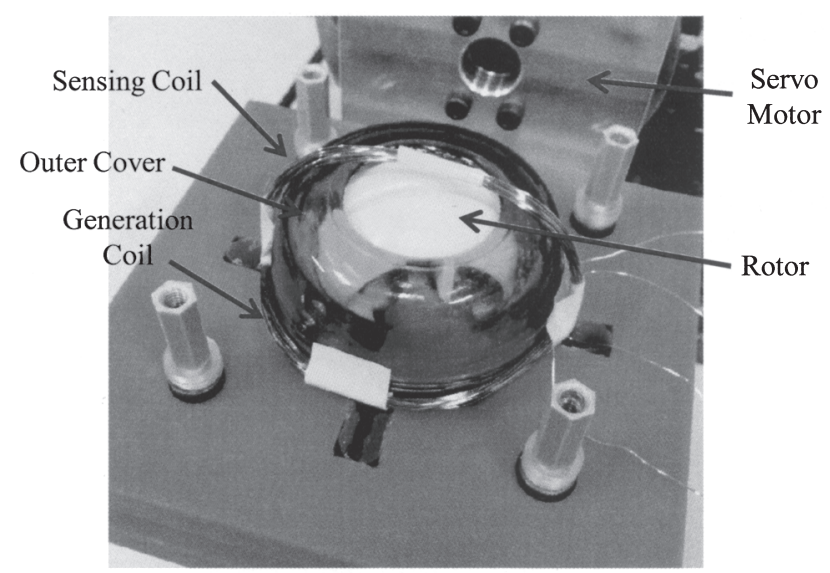

Fig. 11 Appearance of the gyroscopic power generator
センシングコイルはロータ軸と平行なときに電圧最大, 垂直な ときに電圧 0 となる。このため, センシングコイルの振幅最大 の点からサーボモータパルスまでの時間から歳差角 $\alpha$ が求まる

(Fig. 13). 本方法により, 歳差 1 回転ごとに $\varphi$ が計測される. 今回の実験においてインピーダンスは，発電コイルをあらかじ め 10 巻きずつに分割しておき, ショートするコイル数を変化さ せることで変化させた，インピーダンスは，FET などで発電コ イルと負荷の間を細かくオンオフすることでも変化可能である

$\varphi$ の目標值は $\varphi_{s}=0.524[\mathrm{rad}]$ とした. 理想的には理論上の 安定限界である $\varphi=0$ とすべきであるが， $\varphi$ の測定が 1 周期 に 1 回であること, $\varphi$ に測定誤差があること, 過渡状態の安定 限界が厳密には $\varphi=0$ でないこと, インピーダンスを連続的に 変化させられないことなどから，余裕を持たせた．

まず， $\theta_{0}$ を大きくしたときに， $\varphi$ に応じて接続コイル数を変化 させた. 入力振動数は $\omega_{0}=2[\mathrm{~Hz}]$ とした. 初期状態では, $N$ が 10 巻, $\theta_{0}$ は $0.262[\mathrm{rad}], \varphi$ は $0.785[\mathrm{rad}]$ で, $P$ は $0.028[\mathrm{~W}]$ で あった。このとき $\varphi>\varphi_{s}$ なので安定余裕が大きいと判断し, $N$ を 30 巻に増やした. すると, $\varphi=0.524[\mathrm{rad}], P=0.096[\mathrm{~W}]$ となった. $\varphi=\varphi_{s}$ なので, $P$ は最大值であると言える. 次に $\theta_{0}$ を $0.279[\mathrm{rad}]$ に増加すると, $\varphi=0.698[\mathrm{rad}]$ となった. 再 び $\varphi>\varphi_{s}$ となったので, 安定余裕が大きいと判断し， $N$ を 50 巻とした. すると, $\varphi=0.559[\mathrm{rad}], P=0.181[\mathrm{~W}]$ となった. 以上をまとめたものを Table 1 に示す， $P$ はインピーダンス を一定とした場合に比べて，6倍に増大している.

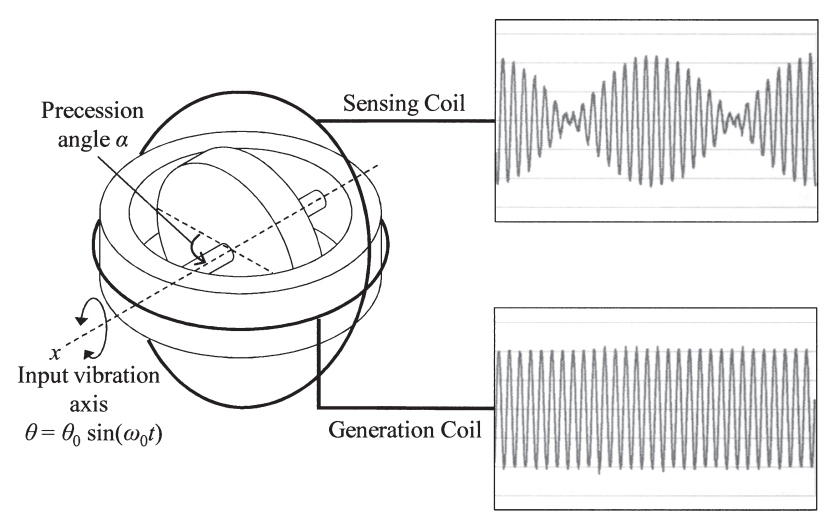

Fig. 12 Voltage wave patterns of the sensing coil and the generation coil

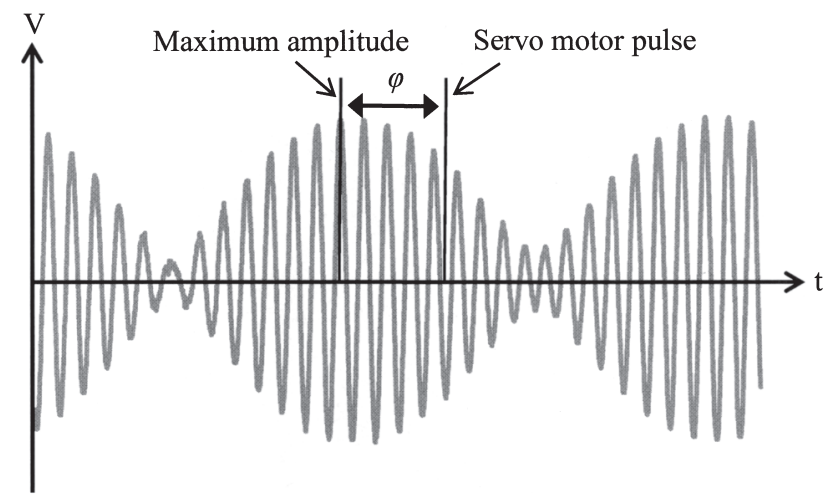

Fig. 13 Relationship among the sensing coil voltage, the vibration pulse, and $\varphi$ 
Table 1 Parameters when the amplitude of the input vibration $\theta_{0}$ is increased

\begin{tabular}{|c|c|c|c|c|}
\hline$\theta_{0}[\mathrm{rad}]$ & 0.262 & 0.262 & 0.279 & 0.279 \\
\hline$N$ & 10 & 30 & 30 & 50 \\
\hline$\varphi[\mathrm{rad}]$ & 0.785 & 0.524 & 0.698 & 0.559 \\
\hline$P[\mathrm{~W}]$ & 0.028 & 0.096 & 0.096 & 0.181 \\
\hline
\end{tabular}

Table 2 Parameters when the amplitude of the input vibration $\theta_{0}$ is decreased

\begin{tabular}{|c|c|c|c|c|c|}
\hline$\theta_{0}[\mathrm{rad}]$ & 0.279 & 0.262 & 0.262 & 0.244 & 0.244 \\
\hline $\mathrm{N}$ & 50 & 50 & 30 & 30 & 10 \\
\hline$\varphi[\mathrm{rad}]$ & 0.559 & 0.349 & 0.524 & 0.349 & 0.750 \\
\hline
\end{tabular}

次に， $\theta_{0}$ を小さくしたときに， $\varphi$ に応じて $N$ を減らすこと で安定状態を維持する実験を行った. 初期状態では, $N=50$ 巻, $\theta_{0}=0.279[\mathrm{rad}], \varphi=0.559[\mathrm{rad}]$ であった. $\varphi>\varphi_{s}$ なので発 電機は安定状態にある．次に $\theta_{0}$ を $0.262[\mathrm{rad}]$ に減少すると, $\varphi$ は過渡的に $0.349[\mathrm{rad}]$ となり, $\varphi<\varphi_{s}$ となったため, 過渡的に 不安定であると判断した。 この過渡状態において $N$ を 30 巻に減 らすと， $\varphi$ は定常状態で $0.524[\mathrm{rad}]$ となった。これは安定状態が 回復したことを示す. 次に, $\theta_{0}$ を $0.244[\mathrm{rad}]$ に減少すると, $\varphi$ は 再び過渡的に $0.349[\mathrm{rad}]$ となり, $\varphi<\varphi_{s}$ となったため, 過渡的 に不安定であると判断した。 この過渡状態において $N$ を 10 巻に 減らすと, $\varphi$ は定常状態で $0.750[\mathrm{rad}]$ となり, 安定状態が回復し た．以上をまとめたものを Table 2 に示す，なお $N$ を変化させ ない場合, $\theta_{0}=0.262[\mathrm{rad}]$ で定常に達することなく失速した.

以上の実験により， $\varphi$ を測定してコイル巻数を変化させるこ とで, 最大発電量と安定状態を維持できることが確認できた。

\section{4. 結論}

携帯情報機器のエネルギー源確保のため, 低周波振動から高 出力の電力を得るジャイロ型発電機の安定化手法を考案した. シ ミュレーションと実験により手法の妥当性を確認し, また受動 素子のパラメー夕調整のみで制御が可能なことを示した。主な 結論を以下に示す.

（1）ロータの定常回転時の安定条件を明らかにした。また入力 振動の変化が遅い場合についてシミュレーションを行い, 入
力振動と歳差回転の位相差が 0 となるように粘性減衰係数 を設定することで, 最大発電量と安定状態を維持できるこ とを示した。

（2）入力振動の変化が大きい場合についてシミュレーションを 行い, 過渡状態においても位相差を 0 とする減衰係数の制 御が有効なことを示した。

（3）センシングコイルによりロー夕歳差角を測定する方法を考 案した。 これを用いて, 位相差の計測值に応じてコイル巻 数を変えることで最大発電量と安定状態を維持できること を示した。

なお本研究は科研費（22360067）の助成を受けたものである.

\section{参 考 文 献}

[1] S. Roundy, P.K. Wright and J.M. Rabaey: Energy Scavenging for Wireless Sensor Networks: with Special Focus on Vibrations. Springer, 2003.

[2] 板生清: “進展する微小エネルギー技術”, 光アライアンス, vol.7, no.7, pp.1-5, 1996.

[ 3 ] 猿渡朋澄, 池田仁志, 野尻和雄: “発電機付腕時計”, 日本時計学会誌, no.120, pp.17-27, 1987.

[4] 長尾昭一, 安川尚昭, 吉野雅士 : “ウオッチ用自動発電機構の開発”, 日本時計学会誌, no.120, pp.40-48, 1987.

[5]長尾昭一：“ウォッチ用自動巻発電機構の改良”, 日本時計学会誌, no.144, pp.22-30, 1993.

[6 ] 原辰男: “小型 AGS（自動巻発電ウォッチ）の開発”, 日本時計学会 誌, no.157, pp.33-42, 1996.

[7] 北原丈二： “薄型 AGS（自動巻発電ウォッチ）の開発”, 日本時計学 会誌, no.158, pp.22-31, 1996.

[8] F.H. Mishler: Gyroscopic device, United States Patent 3726146,1973

[9] D.W. Gulick and O.M. O'Reilly: "On the Dynamics of the Dynabee," Journal of Applied Mechanics-transactions of the ASME, vol.67, no.2, pp.321-325, 2000.

[10] M. Kasahara, H. Yoshida, H. Hosaka and K. Sasaki: "Study on gyroscopic power generator - prototype and its fundamental characteristics," JSME-IIP/ASME-ISPS Joint Conference on Micromechatronics for Information and Precision Equipment (MIPE2009), pp.295-296, 2009.

[11] 石井智裕, 後藤裕治, 小川達也, 保坂寛: “ジャイロ型振動発電機の 研究”, 精密工学会誌, vol.74, no.7, pp.764-768, 2008.

[12] 吉川覚, 岩崎淳, 岸本幹史, 保坂寛, 佐々木健 : “ジャイロ型振動発電機 の過渡応答解析”, 精密工学会誌, vol.76, no.2, pp.238-242, 2010.

[13] Y. Kamiya, H. Hosaka and M. Kasahara: "1st Report of a Study on Gyroscopic Power Generator - Prototype and its Fundamental Characteristics _," TENCON2010, 2010.

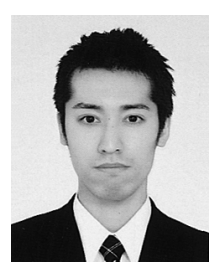

高橋智幸（Tomoyuki Takahashi）

2010 年東京大学工学部精密工学科卒業. 同年東京 大学大学院新領域創成科学研究科博士前期課程入学, 現在に至る. ジャイロ型発電機に関する研究に従事. 精密工学会学生会員.（日本ロボット学会学生会員）

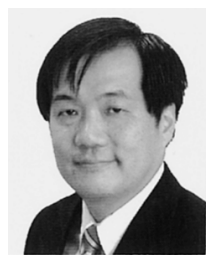

保坂 寛 (Hiroshi Hosaka)

1981 年東京大学大学院工学系研究科修士課程修了 日本電信電話 (株), 東京大学大学院工学系研究科 助教授を経て現在に至る。情報機器, 移動体センシ ング, 機械振動学の教育・研究に従事. 精密工学会, 日本機械学会, 日本時計学会会員.

(日本ロボット学会正会員)

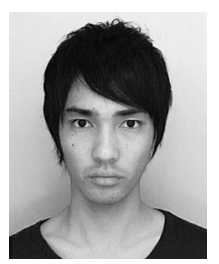

岩崎 淳 (Jun Iwasaki)

2008 年東京大学工学部システム創成学科卒業. 同 年東京大学大学院新領域創成科学研究科入学, ジャ イロ型発電機に関する研究に従事. 2010 年東京大 学大学院新領域創成科学研究科博士前期課程修了. 現在三井住友海上火災保険（株）に勤務。 